\title{
タンニン及び数種の関連化合物のラットのエタノール胃損傷に対する効果
}

谷覚, $*, a$ 桜井裕二, ${ }^{a}$ 近藤嘉和 ${ }^{b}$

城西大学薬学部, ${ }^{a}$ 東北大学薬学部 ${ }^{b}$

\section{Effects of Tannins and Some Related Compounds on Ethanol-Induced Gastric Lesions in the Rat}

\author{
Satoru Tani, ${ }^{*, a}$ YUui Sakurai $^{a}$ and Yoshikazu Kondo ${ }^{b}$ \\ Faculty of Pharmaceutical Sciences, Josai University, ${ }^{a} 1-1$, Keyaki-dai, \\ Sakado, Saitama, 350-02, Japan and Faculty of Pharmaceutical \\ Sciences, Tohoku University, ${ }^{b}$ Aobayama, Sendai, 980, Japan
}

(Received December 17, 1985)

\begin{abstract}
The protective effects of three kinds of typical tannins: gallotannin; tannic acid and gallic acid, ellagitannin; ellagic acid, condensed tannin; bergenin, on ethanol-induced gastric lesions were tested in rats. As the results, ellagic acid and tannic acid showed protective effects. Some related compounds with catechol or its O-methylate or O-methyl pyrogallol moiety were tested. However, these compounds did not show statistically significant effects. Since tannins with pyrogallol moiety were effective for ethanol-induced gastric lesions, a mechanism of the protective effects of ellagic acid and tannic acid was examined. Both compounds lost the effects in indomethacin-treated rats. These results suggested that tannins with pyrogallol moiety showed protective effects for ethanol-induced gastric lesions by stimulating the production of prostaglandins in the gastric mucosa.
\end{abstract}

Keywords - tannin; tannic acid; ellagic acid; pyrogallol; ethanol-induced gastric lesion

従来, 胃腸薬として多くの和漢薬が用いられてきたが，そのなかには，有効成分が同定されたもの，1,2）や有効 画分が認められたもの3) などもあるが，いまだにその薬効・作用が不明なものもある. 我々は用いられている生 薬のなかにタンニンを含むものがあることに注目し種々検討を重ねてきた。その結果, モデル物質として用いた タンニン酸に Shay 潰瘍に対し抗潰瘍作用があること, ${ }^{4)}$ あらかじめ胃内をタンニン酸で処理すると著明に酸分 泌促進物質による反応が低下すること, ${ }^{5)}$ またタンニン酸で胃内を前処理すると胃内容物の十二指腸への排出能 が著しく低下すること常報告した.

最近, 胃病変の新しいモデルとしてェタノール, 塩酸, 苛性ソーダあるいは熱湯を胃内に直接投与して壊死を

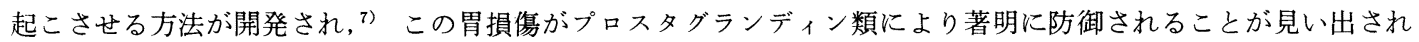
た. 我々もこの胃損傷モデルを用いタンニン等の効果について検討した.

\section{実験 の 部}

エタノール胃損賃の作製＼cjkstart体重約 $200 \mathrm{~g}$ の Wistar 系雄性ラットを $24 \mathrm{~h}$ 絶食, $19 \mathrm{~h}$ 絶水し, Robert らの方 法7) に準じェタノール $1.0 \mathrm{ml}$ をゾンデにて経口的に胃内に直接投与した. 試薬は $1.0 \mathrm{ml}$ の水に溶解もしくは懸 濁しエタノール投与 $30 \mathrm{~min}$ 前に同じく経口投与した. インドメタシン前処理に際してはインドメタシンを $0.5 \%$ カルボキシメチルセルロースに懸濁し $5 \mathrm{mg} / \mathrm{kg}$ の量をエタノール投与 $1 \mathrm{~h}$ 前に皮下投与した. 胃損傷の程 度はエタノール投与 $1 \mathrm{~h}$ 後にラットをエーテル麻酔下開腹し胃を摘出後, $10 \mathrm{ml}$ の $2 \%$ ホルマリンを胃内に注 入・固定し胃粘膜の出血性損傷を測定し, その長さの総和を $\mathrm{mm}$ で表した. 結果の統計的処理は student の $t$ 検 定によった。

試薬 Bergenin は同仁医薬化工より恵与された. 3,3'-O-Dimethyl ellagic acid はノウルシ (Euphorbia adenochlora) から抽出・精製したもの8) を用いた. その他の試薬は次のところから入手し用いた； tannic acid (小宗 薬品), ellagic acid (Aldrich), gallic acid, protocatechuic acid (和光純薬), caffeic acid, ferulic acid, indome- 
thacin (Sigma).

\section{実験 結果及び考察}

\section{タンニン及び数種の関連化合物のエタノール胃損傷に対する効果}

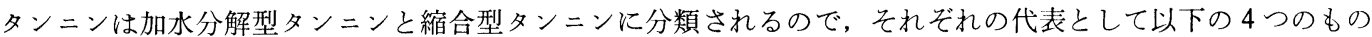
を選んだ。すなわち,ガロタンニンの tannic acid と gallic acid, エラグタンニンの ellagic acid, それに縮合型 タンニンで有効性が認められている bergenin ${ }^{9)}$ である. 以上 4 種の化合物について投与量を $25,50,100 \mathrm{mg} / \mathrm{kg}$ としェタノール胃損傷に対する効果を調べた (Fig. 1). Tannic acidは $100 \mathrm{mg} / \mathrm{kg}$ で $5 \%$ の危険率で有意に防御 作用を示した。しかし tannic acid のアグリコンである gallic acid では防御効果は弱く有意差は認められなかっ た. 同じ加水分解型タンニンの ellagic acid には強い防御効果が認められ, $25 \mathrm{mg} / \mathrm{kg}$ で $5 \%$ の, 50 及び $100 \mathrm{mg} /$ $\mathrm{kg}$ では $1 \%$ の危険率で有意であった．しかし縮合型タンニンの bergenin では防御効果が全く認められなかっ た.これらのことからポリフェノールに効果が期待されたので, 関連する若干の化合物について検討した.すな わち, ellagic acidの 3 及び $3^{\prime}$ 位の水酸基がメチル化された 3,3'-O-dimethyl ellagic acid, カテュールで芳香環 に直接カルボキシル基を持つ protocatechuic acid と側鎖にカルボキシル基を持つ caffeic acid 及びその $O$-メチ ル体の ferulic acid の 5 つを選んだ。化合物は水に懸濁し投与量を $100 \mathrm{mg} / \mathrm{kg}$ とし前と同様経口投与した(Table I). 3,3'-O-Dimethyl-ellagic acid はエタノール胃損傷を防御する傾向を示したが有意差は認められず， ellagic acidの水酸基の重要性が示された. Ferulic acid や protocatechuic acidにも弱い防御作用が認められたが有意 でなく, caffeic acid には全く効果がみられなかった．以上のことから，ピロガロール構造にエタノール胃損傷防 御作用が認められた。すでに hydroquinone や propyl gallate には低用量でプロスタグランディン生合成促進作

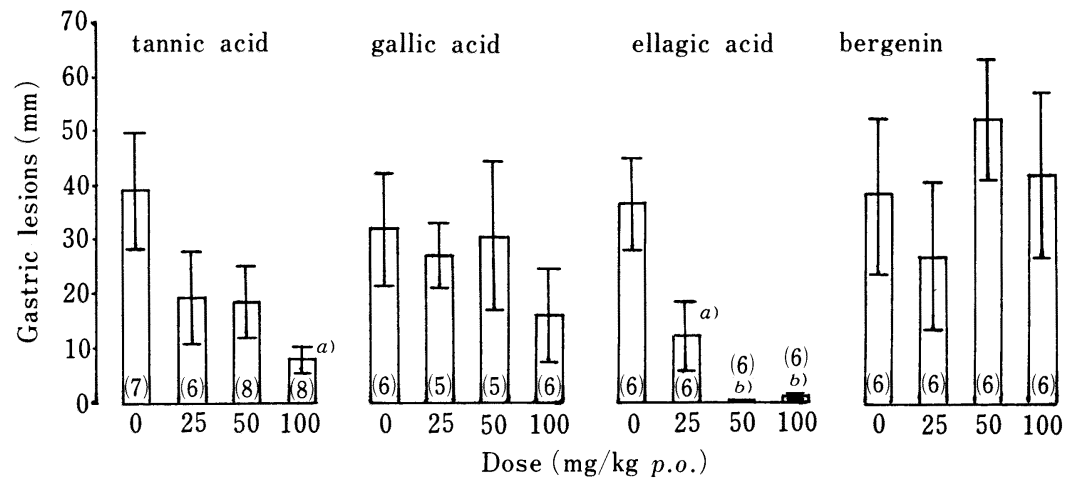

Fig. 1. Effects of Tannins on Ethanol-Induced Gastric Lesions in the Rat

The values represent mean \pm S.E. The numbers of rats are given in parentheses. $a$ ) $p<0.05, b$ ) $p<0.01$.

TABle I. Effects of Tannin-Related Compounds on Ethanol-Induced Gastric Lesions in the Rat

\begin{tabular}{lrc}
\hline \multicolumn{1}{c}{ Compound $^{a)}$} & $\begin{array}{c}\text { No. } \\
\text { of } \\
\text { rats }\end{array}$ & $\begin{array}{c}\text { Gastric } \\
\text { lesions }^{b)} \\
(\mathrm{mm})\end{array}$ \\
\hline Control $^{c)}$ & 10 & $26.5 \pm 6.8$ \\
$3,3^{\prime}-O$-Dimethyl ellagic acid & 8 & $10.0 \pm 3.4$ \\
Protocatechuic acid & 9 & $19.3 \pm 8.7$ \\
Caffeic acid & 8 & $28.3 \pm 4.9$ \\
Ferulic acid & 8 & $12.3 \pm 2.2$
\end{tabular}

a) Dose; $100 \mathrm{mg} / \mathrm{kg}$ in water $(1 \mathrm{ml})$, p.o. b) The values represent mean $+S$.E. c) Water $(1 \mathrm{ml})$.
TABLE II. Effects of Tannic Acid and Ellagic Acid on Ethanol-Induced Gastric Lesions in Indomethacin-Treated Rats

\begin{tabular}{lcc}
\hline \hline Treatment & $\begin{array}{c}\text { No. of } \\
\text { rats }\end{array}$ & $\begin{array}{c}\text { Gastric lesions } \\
(\mathrm{mm})\end{array}$ \\
\hline Control $^{b)}$ & 6 & $34.3 \pm 6.0$ \\
Tannic acid $^{c)}$ & 6 & $64.8 \pm 9.5$ \\
Control $^{b)}$ & 5 & $66.2 \pm 11.8$ \\
Ellagic acid $^{c)}$ & 5 & $77.4 \pm 6.8$ \\
\hline
\end{tabular}

a) The values represent mean \pm S.E b) Water. c) Dose; $100 \mathrm{mg} / \mathrm{kg}$ in water $(1 \mathrm{ml})$, p.o. 
用 ${ }^{10)}$ がまた aspirin には阻害作用が知られているので, フェノール化合物の構造のわずかな違いによりプロスタ グランディンの生合成が促進されたり，阻害されたりする可能性が示唆される. また caffeic acid にはリポキシ ゲナーゼの阻害作用が認められている ${ }^{11)}$ が，今回の実験結果と考え合わせると，エタノール胃損傷の発生には口 イコトリエン等の関与は少ないと考えられる.

\section{インドメタシン処理ラットにおけるエタノール胃損傷に対する Tannic Acid 及び Ellagic Acid の効果}

あらかじめインドメタシン $5 \mathrm{mg} / \mathrm{kg}$ を皮下投与したラットを用い, エタノール胃損傷を作製しタンニンの効果 を検討した. タンニンの投与量は $100 \mathrm{mg} / \mathrm{kg}$ とし, 結果を Table II に示した. Tannic acid と ellagic acid のエ タノール胃損傷防御作用はインドメタシン処理により消失し, むしろ悪化させる傾向が認められた. Robert ら は弱い壊死性因子を前投与することにより続いて投与される強い壊死性因子の作用が減弱されることを認め, こ のことに対し “adaptive cytoprotection”といら概念を与えた. ${ }^{12)}$ もしタンニンの作用が弱い壊死性因子と全く 同様の作用をするとすれば，インドメタシン処理によっても対照以上の増悪は見られないはずである. しかし我 々の結果ではタンニンは胃粘膜に対し増悪的に作用しているので, タンニンの作用はプロスタグランディン生合 成促進のみでなく，ここでは不明であるが他の作用の存在も考えられる. 通常の胃粘膜では適当な量のタンニン は障害作用を示すことなく, 逆にプロスタグランディン類の生合成を促進し健胃的な効果を及法していると考え られ，胃腸薬中のタンニン含有生薬の配合意義も一部このように説明されるかもしれない.

\section{引用 文 献}

1) 荘司行伸, 門河敏明, 増田義信, 河島勝良, 中村圭二, 日薬理, 65, 196 (1969).

2) G. Clavenna, R. Musci, L. Dorigotti, J. Pharm. Pharmacol., 34, 517 (1982).

3) Y. Ishii, Y. Fujii, Jpn. J. Pharmacol., 32, 23 (1982).

4) 谷 覚, 薬誌, 96, 648 (1976).

5) S. Tani, Chem. Pharm. Bull., 26, 309 (1978).

6) 谷覚, 山㥓 浩, 武藤徳男, 薬誌, 103, 225 (1983).

7) A. Robert, J. E. Nezamis, C. Lancaster, A. J. Hanchar, Gastroenterology, 77, 433 (1979).

8) Y. Kondo, T. Toida, G. Kusano, J. Imai, Experientia, 35, 599 (1979).

9) 岡田 勉, 鈴木 勉, 羽曽部すま, 木皿憲佐, 日薬理, 36, 369 (1973).

10) D. H. Nugteren, R. K. Beerthuis, D. A. Van Dorp, Rec. Trav. Chim., 85, 405 (1966).

11) Y. Koshihara, T. Neichi, S. Murota, A. Lao, Y. Fujimoto, T. Tatsuno, Biochim. Biophys. Acta, 792, 92 (1984).

12) A. Robert, J. E. Nezamis, C. Lancaster, J. P. Davis, S. O. Field, A. J. Hanchar, Am. J. Physiol., 245, G113 (1983). 